\title{
Low-level laser therapy and Calendula officinalis in repairing diabetic foot ulcers*
}

\author{
Terapia a laser de baixa intensidade e Calendula officinalis \\ no reparo de úlcera em pé diabético \\ Terapia con láser de baja intensidad y Calendula officinalis \\ en la reparación de úlcera en pie diabético
}

\begin{abstract}
Ana Flávia Machado de Carvalho ${ }^{1}$, Maura Cristina Porto Feitosa ${ }^{1}$, Nayana Pinheiro Machado de Freitas Coelho ${ }^{1}$, Veruska Cronemberger Nogueira Rebêloº , Juçara Gonçalves de Castro², Patrícia Regina Gomes de Sousa², Valrian Campos Feitosa $^{2}$, Emilia Angela Lo Schiavo Arisawa ${ }^{3}$
\end{abstract}

How to cite this article:

Carvalho AFM, Feitosa MCP, Coelho NPMF, Rebêlo VCN, Castro JG, Sousa PRG, et al. Low-level laser therapy and Calendula officinalis in repairing diabetic foot ulcers. Rev Esc Enferm USP. 2016;50(4):626-632. DOI: http://dx.doi.org/10.1590/S0080-623420160000500013

\footnotetext{
* Extracted from the theses "Efeito da Terapia a Laser de Baixa Intensidade com Calendula officinalis no reparo de úlcera em pé diabético", Universidade do Vale do Paraíba, 2015.

${ }^{1}$ Universidade Estadual do Piauí, Faculdade de Ciências Médicas, Teresina, PI, Brazil.

${ }^{2}$ DeVry|Facid,Teresina PI, Brazil.

${ }^{3}$ Universidade do Vale do Paraíba, Instituto de Pesquisa e Desenvolvimento, São José dos Campos, SP, Brazil.
}

\begin{abstract}
Objective: To evaluate the effects of low-level laser therapy isolated and associated with Calendula officinalis oil in treating diabetic foot ulcers. Method: An experimental, randomized, controlled, prospective, interventional clinical case study using a quantitative approach. The sample consisted of 32 diabetic patients of both genders. Participants were randomly divided into four groups. Doppler Ultrasound evaluation of the Ankle-Brachial Index, brief pain inventory and analog pain scale were performed at baseline and after 30 days. Results: Reduced pain was observed in the Low-level laser therapy and Lowlevel laser therapy associated with Essential Fatty Acids groups $(p<0.01)$. Regarding the Ankle-Brachial Index and Doppler Ultrasound, all groups remained stable. By analyzing lesion area reduction, Low-level laser therapy associated with Essential fatty acids group showed a significance of $\mathrm{p}=0.0032$, and the Low-level laser therapy group showed $p=0.0428$. Conclusion: Low-level laser therapy, performed alone or associated with the Calendula officinalis oil was effective in relieving pain and accelerating the tissue repair process of diabetic foot.
\end{abstract}

\section{DESCRIPTORS}

Calendula Officinalis; Diabetes Mellitus; Diabetic Foot; Laser Therapy. 


\section{INTRODUCTION}

Diabetes Mellitus (DM) is a metabolic syndrome characterized by the prevalence of hyperglycemia, resulting from a deficiency of insulin secretion and/or its inability to properly perform its functions. Among the many consequences of this disease, we can highlight slow repair/healing of anatomical and functional tissue integrity, having negative repercussions on various biochemical and cellular events which are involved in tissue response to injury, which are also dependent on the repair quality ${ }^{(1-2)}$.

DM complications have a degenerative character and usually occur in a time interval of 5 to 10 years after disease onset. In the eyes, the occurrence of retinopathy can be observed, being responsible for blindness; also, renal failure of the kidneys; acceleration of atherosclerosis (macrovascular disease) with higher risks for myocardial infarction or stroke; and peripheral neuropathy associated with atherosclerosis of small vessels, making the individual susceptible to developing ischemic and infectious problems in the extremities, which may develop into a condition of ulceration, gangrene and even limb amputation ${ }^{(3)}$.

In a study of amputations performed in England from surveying the National Health Service Hospitals data (UK), the importance of a multidisciplinary approach has been proven in treating diabetic foot ulcers and the infection itself by surgical procedures, revascularization and physical therapy rehabilitation with the application of electrical resources and phototherapy have been effective in controlling edema, pain, metabolic disorders, tissue malnutrition, co-morbidities, meticulous wound care and biomechanical decompression ${ }^{(4)}$.

Low-level laser therapy (LLLT) is presented as a lowcost and efficient therapeutic resource proven in treating ulcers, able to accelerate the repair process in different tissues by employing low-power light sources such as Light Emitting Diode - LED, which may also be used in association with alternative therapies such as the use of Essential Fatty Acids (EFAs) ${ }^{(5)}$.

A type of EFA is Calendula officinalis, being very common in the Mediterranean and popularly known as marigold. Topical use of oil from this plant has been suggested as a therapeutic resource by the National Health Surveillance Agency (Agência Nacional de Vigilância Sanitária - ANVISA) due to its anti-inflammatory therapeutic and healing effects ${ }^{(6)}$. It is recommended for treating superficial lesions such as burns and bedsores, wounds and skin ulcers ${ }^{(7)}$.

Thus, this study aimed to assess the effects of isolated LLLT and LLLT associated with Calendula officinalis oil in the healing process of diabetic foot ulcers.

\section{METHOD}

This is an experimental, randomized, controlled, prospective, interventional clinical case study using a quantitative approach and developed in the Diabetes Treatment Reference Center in Teresina-PI, Brazil, from March 2015 to October 2015. The sample was randomized and simple, consisting of 32 patients. Eligibility criteria were decompensated type II diabetic patients of both genders, aged 40-70 years with fasting blood glucose values between 150 and $350 \mathrm{mg} / \mathrm{dL}$, presenting an ulcer in the lower limb and were being followed at the Diabetic foot outpatient clinic.

Participants were randomly distributed in four groups: 1. Control (C) 2. Low-Level Laser Therapy (L) 3. Essential fatty acids (EFA) and 4. LLLT associated with EFA (LEFA).

At first, patients from this diabetic patient care reference center were evaluated by an angiologist who characterized the ulcer through clinical evaluation, Doppler Ultrasound (US) (SAMSUNG) and Ankle-Brachial Index (ABI). This procedure was performed on the first day and after 30 days of follow-up, corresponding to the expected time for completing the treatment protocol.

Doppler US was used to evaluate peripheral circulation parameters of the lower limbs by a comparative analysis of the size (diameter in $\mathrm{cm}$ ) of arteries: femoral, popliteal, anterior tibial, posterior tibial and fibular, throughout their lengths ${ }^{(8)}$. The posterior tibial artery was analyzed in this study due to its importance in the distal vascularization of lower limbs.

ABI was performed since it is a simple, non-invasive, inexpensive and highly reliable method that provides a systolic blood pressure ratio of the ankle and arm. The ABI calculation is obtained from the highest systolic blood pressure ratio of the posterior tibial artery and the dorsal artery of the foot, for both limbs or just one depending on which are affected, with the highest systolic pressure of the brachial arteries. $\mathrm{ABI}$ values $\leq 0.90$ or $>1.30$ are considered abnormal and represent cardiovascular risk markers ${ }^{(9)}$.

After medical evaluation, careful kinetic and functional evaluation of the patients was performed by the physiotherapist consisting of personal data and history regarding their Diabetes and lower limb ulcers through a specific evaluation form. Volunteers who agreed to participate were enrolled in the study only after the evaluations.

Before the start of the intervention protocol, patients were subjected to a procedure for ulcer characterization which consisted of measuring the wound using a measuring tape with $\mathrm{cm}$ division, conducted during the first and last appointment, after completing the treatment protocol. Data were analyzed by Image $\mathrm{J}^{\oplus}$ software, which uses the circumscription of the wound edges as reference for measurement in square centimeters $\left(\mathrm{cm}^{2}\right)$, thereby calculating the total area of the injury. The wounds had to be located in the foot, or in the medial or distal third of the leg, and measuring between 1 and $5 \mathrm{~cm}$ length.

The Brief Pain Inventory Questionnaire and the Visual Analogue Scale (VAS) were applied in order to identify pain quantification and its interference on quality of life and carrying out functions, the latter focused on patients with difficulties in measuring pain numerically.

Group $\mathrm{C}$ volunteers were instructed and made aware of the need to clean the ulcers every day and to apply dressing without the assistance of the researcher. After 30 days, 
they returned to the physiotherapy service for the revaluation process with Doppler US, ABI, pain scales and macroscopic imaging.

Group L participants were subjected to the following protocol: $658 \mathrm{~nm}, 30 \mathrm{~mW}$ power, 80 s application time $\left(4 \mathrm{~J} / \mathrm{cm}^{2}\right)$, continuous wave, visible beam, on an area equivalent to $12.566 \mathrm{~mm}^{2}$ (Laser - HTM manufacturer). For the purposes of LLLT, the pen was held perpendicular to the wound with punctual contact, and at equidistant points around and on the wound bed. Wound protection was made with transparent film. Initially, the wound was cleaned with a sodium chloride solution ( $0.9 \%$ saline), removing the excess with sterile gas. Both the physiotherapist and the patient used goggles during each phototherapy intervention. Twelve meetings were held in total, corresponding to three weekly sessions, every other day.

For the EFA group, the therapeutic protocol implemented was: wound washed daily with sodium chloride solution ( $0.9 \%$ saline), removing the excess with the aid of sterile gas. Subsequently, $5 \mathrm{~mL}$ calendula oil (Embrafarma) was applied once a day for 30 days.

For the LEFA group, LLLT was initially applied according to the protocol mentioned in group L, and calendula oil (Embrafarma) was subsequently applied as described for the EFA group, followed by a dressing. The oil was applied during the 30 days of therapeutic protocol for this group; oil was applied alone in the days that LLLT was not applied.

The therapist applied the dressing at the end of each visit, being careful to cover the wound area with sterile gases, bandage and micropore $\left(\mathrm{Nexcare}^{\circledR}\right)$, independent of protocol. The non-disposable materials used in the procedure were sanitized by immersion for 12 hours in 30\% nitric acid, rinsed in milli- $\mathrm{Q}^{\mathrm{R}}$ water and dried in an oven.

Once collected, the data were organized in spreadsheets in the Microsoft Office Excel 2010 program for distribution among specific groups. Subsequently, the normality test was performed (Passed Normality Test), also being organized into charts and a table. For intragroup comparison, the variable averages were calculated by the "Student's t" program, and the "One-way ANOVA post hoc Tukey test" was applied for intergroup comparison, both with $95 \%$ confidence intervals and significance established at $p<0.05$. Finally, data analysis was performed using the Graph Pad Prism 5.0 statistical program.

This study was developed according to the specifications of 466/12 resolution of the National Health Council and submitted for approval to the Research Ethics Committee, and started only after approval by the Research Ethics Committee of the Faculdade Integral Diferencial, protocol number 40818114.4.0000.5211. Data collection for the study was carried out with permission from the institution, and the signing of the Informed Consent Form (ICF) by the participants.

\section{RESULTS}

Posterior tibial artery caliber was recorded by Doppler US. Figure 1 shows that there was no statistically significant difference within groups, meaning the data remained constant until the end of the therapeutic protocols were performed.

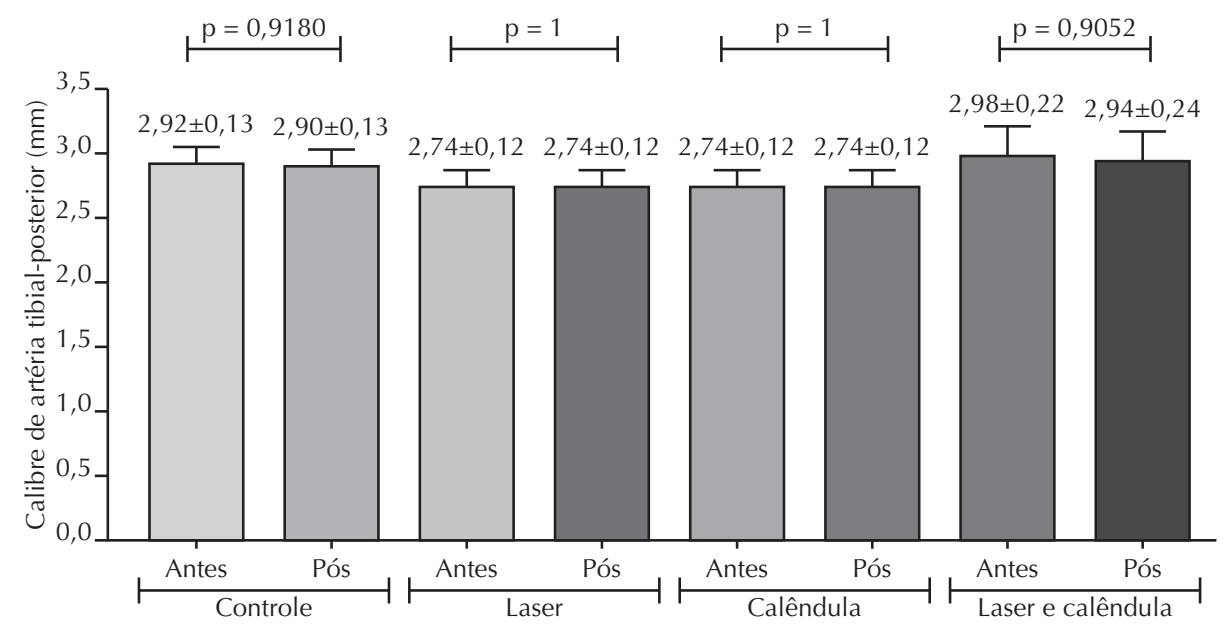

Figure 1 - Comparative statistical analysis of the evaluation values of the caliber of the posterior tibial artery in each group - Teresina, Piauí, Brazil, 2015.

Figure 2 indicates that the pressure measurement by ABI showed no statistical difference for intragroup significance.

Data related to quantitative pain perception by the participants from applying the Brief Pain Inventory and VAS analogue scale (represented in Figure 3) show that there was a statistically significant reduction for pain in $\mathrm{L}(\mathrm{p}<0.001)$ and LEFA groups ( $\mathrm{p}<0.001$ ), evidencing that LLLT has an analgesic effect being isolated or associated with Calendula officinalis oil.
There was a significant reduction of wound area in LEFA group ( $p=0.0032)$ and in L group $(p=0.0428)$. Group $\mathrm{C}$ showed significance contrary to the objective $(p=0.3402)$ due to the absence of intervention. These data are shown in Figure 4.

Table 1 shows intergroup behavior of the variables pain, ABI, US application and size of the wound area before and after protocol completion. 


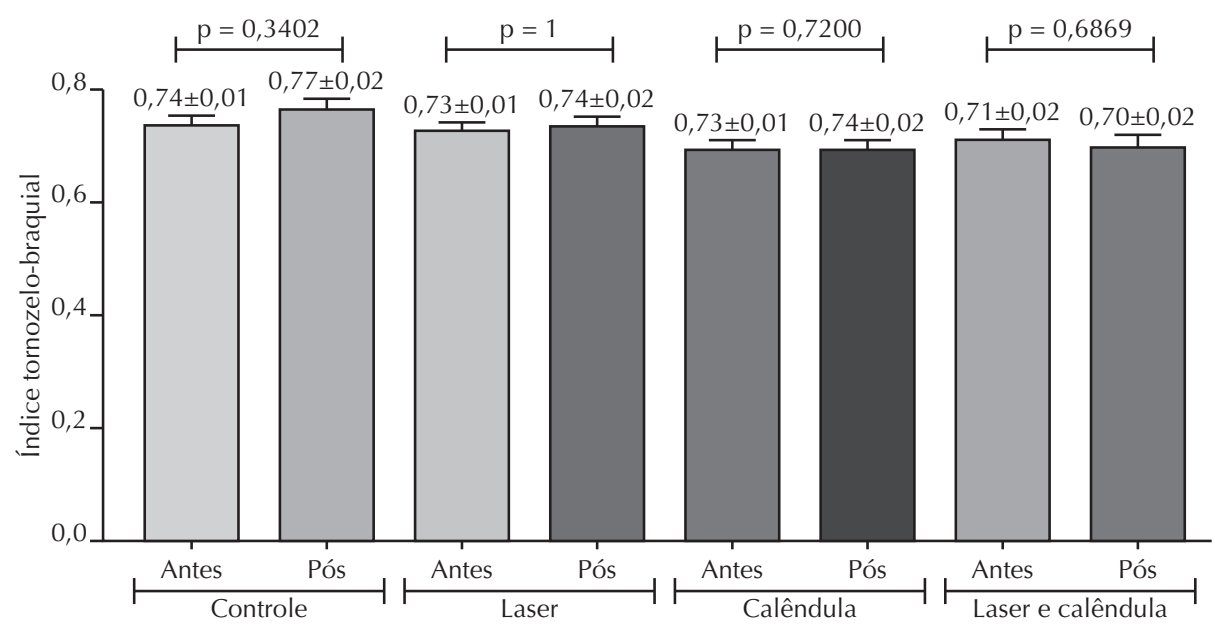

Figure 2 - Comparative statistical analysis of ABI values in each group - Teresina, Piauí, Brazil, 2015.

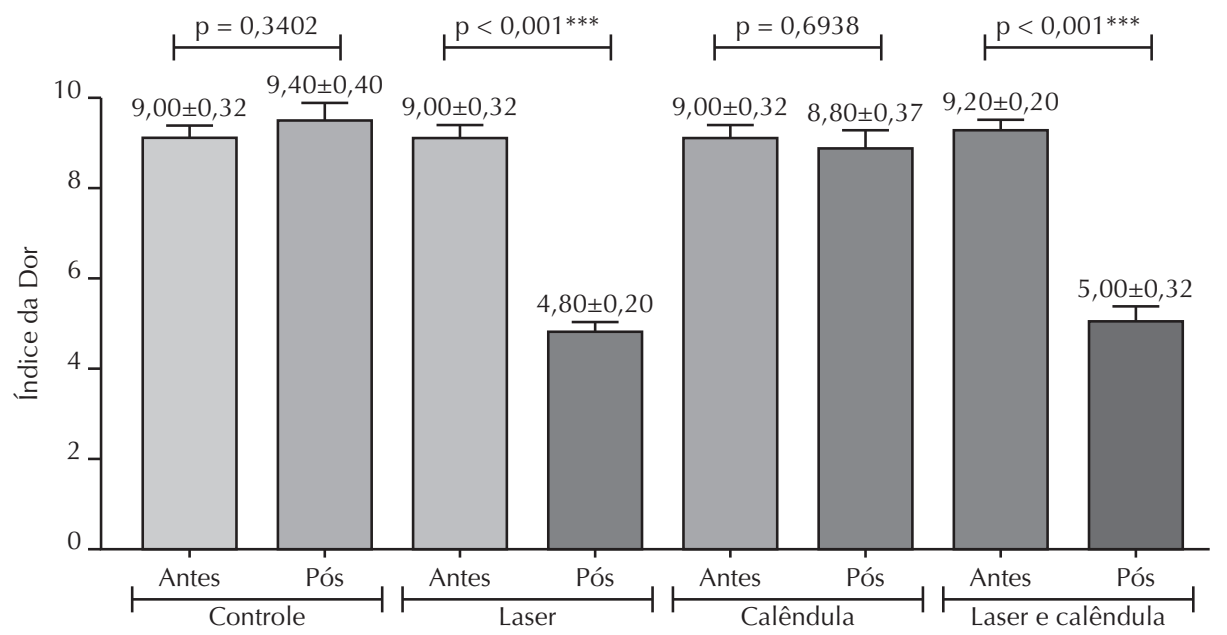

Figure 3 - Comparative statistical analysis of quantitative pain assessment values in the groups - Teresina, Piauí, Brazil, 2015.

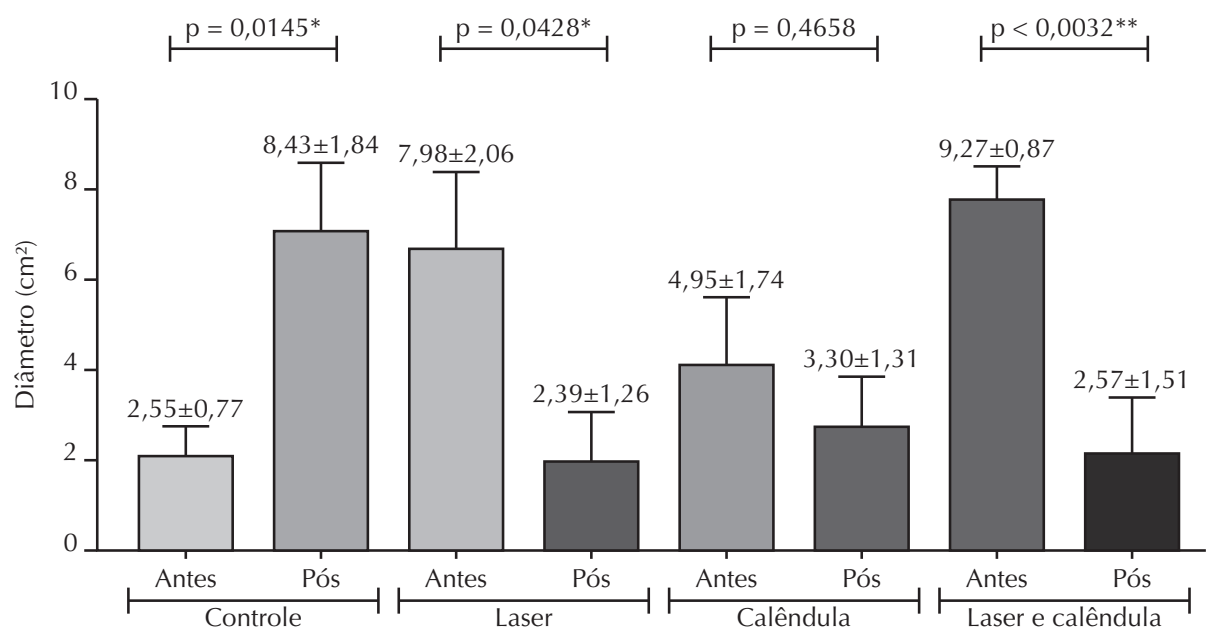

Figure 4 - Comparative statistical analysis of the values obtained by assessment of the total ulcer area in the groups - Teresina, Piauí, Brazil, 2015. 
Table 1 - Intergroup assessment of pain, ABI, US, and wound area by Tukey test after ANOVA evaluation, with 95\% confidence interval and significance at $\mathrm{p}<0.05$ - Teresina, Piauí, Brazil, 2015.

\begin{tabular}{|c|c|c|c|c|c|c|c|c|c|}
\hline \multirow{2}{*}{\multicolumn{2}{|c|}{ Pain }} & \multicolumn{2}{|c|}{ C } & \multicolumn{2}{|c|}{$\mathbf{L}$} & \multicolumn{2}{|c|}{ EFA } & \multicolumn{2}{|c|}{ LEFA } \\
\hline & & Pre & Post & Pre & Post & Pre & Post & Pre & Post \\
\hline \multirow{2}{*}{$\mathrm{C}$} & Pre & - & 0.0056 & 0.1695 & $<0.001^{* * *}$ & $0.0104^{* *}$ & $<0.001^{* * *}$ & 0.2283 & 0.0170 \\
\hline & Post & - & - & 0.1445 & $<0.001^{* * *}$ & 0.0009 & $0.012^{* *}$ & 0.2782 & 0.2782 \\
\hline \multirow{2}{*}{$\mathbf{L}$} & Pre & - & - & - & $0.0199^{* *}$ & 0.2666 & $<0.001^{* * *}$ & 0.5370 & 0.5370 \\
\hline & Post & - & - & - & - & $<0.01^{* *}$ & $0.048^{*}$ & $0.0355^{*}$ & $0.0357^{*}$ \\
\hline \multirow{2}{*}{ EFA } & Pre & - & - & - & - & - & $0.0086^{* *}$ & 0.1340 & $0.0136^{* *}$ \\
\hline & Post & - & - & - & - & - & - & $0.0268^{* *}$ & 0.6202 \\
\hline \multirow{2}{*}{ LEFA } & Pre & - & - & - & - & - & - & - & $0.0179^{*}$ \\
\hline & Post & - & - & - & - & - & - & - & - \\
\hline \multirow{2}{*}{\multicolumn{2}{|c|}{$\mathrm{ABI}$}} & \multicolumn{2}{|c|}{ C } & \multicolumn{2}{|c|}{$\mathbf{L}$} & \multicolumn{2}{|c|}{ EFA } & \multicolumn{2}{|c|}{ LEFA } \\
\hline & & Pre & Post & Pre & Post & Pre & Post & Pre & Post \\
\hline \multirow{2}{*}{$\mathrm{C}$} & Pre & - & 0.4917 & 0.9025 & 0.9559 & $0.0111^{*}$ & $0.0214 *$ & $0.0192 *$ & 0.0113* \\
\hline & Post & - & - & 0.4215 & 0.5173 & $0.0484 *$ & $0.002^{* *}$ & $<0.001^{* * *}$ & $<0.001^{* * *}$ \\
\hline \multirow{2}{*}{$\mathbf{L}$} & Pre & - & - & - & $<0.001 * * *$ & 0.7008 & 0.717 & 0.8036 & 0.9295 \\
\hline & Post & - & - & - & - & 0.6083 & 0.9693 & 0.9209 & 0.8538 \\
\hline \multirow{2}{*}{ EFA } & Pre & - & - & - & - & - & $0.0269 *$ & 0.0626 & 0.0799 \\
\hline & Post & - & - & - & - & - & - & $<0.001^{* * *}$ & $0.025^{*}$ \\
\hline \multirow{2}{*}{ LEFA } & Pre & - & - & - & - & - & - & - & $0.027^{*}$ \\
\hline & Post & - & - & - & - & - & - & - & - \\
\hline \multirow{2}{*}{\multicolumn{2}{|c|}{ Artery caliber }} & \multicolumn{2}{|c|}{$\mathrm{C}$} & \multicolumn{2}{|c|}{$\mathbf{L}$} & \multicolumn{2}{|c|}{ EFA } & \multicolumn{2}{|c|}{ LEFA } \\
\hline & & Pre & Post & Pre & Post & Pre & Post & Pre & Post \\
\hline \multirow{2}{*}{$\mathrm{C}$} & Pre & - & 0.3458 & 0.1112 & 0.2139 & 0.3699 & 0.1391 & 0.4458 & 0.4963 \\
\hline & Post & - & - & 0.6896 & 0.6525 & 0.0664 & 0.1418 & 0.8122 & 0.6774 \\
\hline 1 & Pre & - & - & - & $0.0199 *$ & $0.0357^{*}$ & $0.012^{*}$ & 0.2615 & 0.4327 \\
\hline & Post & - & - & - & - & 0.304 & 0.9292 & 0.3337 & 0.5912 \\
\hline FFA & Pre & - & - & - & - & - & 0.3458 & 0.7165 & 0.4588 \\
\hline & Post & - & - & - & - & - & - & 0.8452 & 0.8612 \\
\hline IFFA & Pre & - & - & - & - & - & - & - & $0.0179^{*}$ \\
\hline LEFA & Post & - & - & - & - & - & - & - & - \\
\hline Woung & (cm) & & & & & & & & \\
\hline Vount & ed (cin) & Pre & Post & Pre & Post & Pre & Post & Pre & Post \\
\hline$C$ & Pre & - & 0.4576 & 0.3445 & 0.7691 & 0.2768 & 0.2685 & 0.0797 & 0.1546 \\
\hline$c$ & Post & - & - & 0.62 & $0.041^{*}$ & 0.9932 & 0.9436 & $0.0211^{*}$ & 0.0627 \\
\hline 1 & Pre & - & - & - & $0.0199 *$ & 0.7145 & 0.6637 & 0.5869 & 0.3609 \\
\hline & Post & - & - & - & - & 0.4854 & 0.6238 & 0.7465 & 0.6045 \\
\hline FFA & Pre & - & - & - & - & - & $<0.001^{* * *}$ & 0.3014 & 0.0955 \\
\hline LrA & Post & - & - & - & - & - & - & 0.3384 & 0.1072 \\
\hline IFFA & Pre & - & - & - & - & - & - & - & $0.0179 *$ \\
\hline LEFA & Post & - & - & - & - & - & - & - & - \\
\hline
\end{tabular}

Legend: C. control; L. Laser; EFA. Calendula; LEFA. Laser associated with Calendula. Source: Original data.

\section{DISCUSSION}

A study of 189 patients with diabetic foot used lower limb Doppler US to check the degree of stenosis of the arteries, classifying them in two ways: reduction in diameter indicated by values < or $=$ to $50 \%$ and complete occlusion for values in between 51 and 99\%. The results showed that the evaluated arteries were compromised, and that the ultrasound was crucial in detecting vascular disorders caused by DM, especially with risk of occlusion ${ }^{(10)}$, thus agreeing with the findings of this study in which a decrease in the diameter of the posterior tibial artery was detected, without a difference in post-intervention values.

Regarding the importance of the ABI, the authors consider that its alterations represent an important marker of 
cardiovascular and peripheral vascular disorders, since the observation of altered values in diabetic patients contributes to determining or evidencing higher probability of the onset of Peripheral Arterial Occlusive Disease (POAD). Patients who have this index out of the normal range should be accompanied by a specialized medical team because they present a risk of recurrent ulcers and consequently serious risk of lower limb amputation ${ }^{(11)}$.

A study performed on 32 volunteers with the objective to compare $\mathrm{ABI}$ values among older adult diabetic and non-diabetic patients showed that diabetics are more likely to develop POAD ${ }^{(12)}$. Therefore, it can be said that this research supports the cited authors, since this study was accurate in detecting pressure changes in the posterior tibial artery, despite the applied protocols in the three intervention groups not providing evidence of statistical significance regarding the improvement of the alterations, as ABI remained without significant intragroup variations. There was post-intervention significance in L and LEFA groups in the intergroup analysis.

The definition of the therapeutic protocol and the choice for the wavelength of $658 \mathrm{~nm}$, peak power of $30 \mathrm{~mW}$, and application time of $80 \mathrm{~s}\left(4 \mathrm{~J} / \mathrm{cm}^{2}\right)$ in this study had published articles as reference which also used LLLT as a proposal for pain treatment and tissue repair, suggesting that wavelengths between 600 and $1000 \mathrm{~nm}$ and power of $1 \mathrm{~mW}$ to $5 \mathrm{~W} /$ $\mathrm{cm}^{2}$ have satisfactory effects. LLLT application has also been mentioned in order to promote better healing of inflammation, reduced pain, preventing occurrence of edema, as well as for preserving tissues and nerves adjacent to the injury site ${ }^{(13)}$.
New drugs have additionally been used in the treatment of cutaneous lesions in patients with DM, with the purpose of speeding up the tissue repair process. Recently, studies of medicinal plants have been highlighted, as these favor the neovascularization process and collagen fiber formation in the tissue repair process, with analgesic, anti-inflammatory and antiseptic action ${ }^{(14-15)}$. These studies corroborate the findings of the present study, since ulcer hydration in diabetic patients with vascular lesions using Calendula officinalis oil was crucial for accelerating the tissue repair process, for both intragroup and intergroup.

Thus, the results of this study are in agreement with the abovementioned authors, since the effect of applying Calendula officinalis oil alone or associated with LLLT as a therapeutic protocol presented positive results on the patients' conditions. Figure 3 shows an increase in pain symptoms for group C. By analyzing the intergroup values, Groups L, EFA and LEFA showed significance. Therefore, the need to implement care protocols for these patients in order to avoid the consequences of DM is evident.

\section{CONCLUSION}

We conclude that LLLT isolated or in combination with Calendula officinalis oil is effective in relieving pain due to its anti-inflammatory action, and in reducing the total area of ulcers by stimulating neovascularization and accelerating cell proliferation, thereby contributing to improving possible morbidities that may occur as consequence of Diabetes Mellitus.

\section{RESUMO}

Objetivo: Avaliar os efeitos da Terapia a Laser de Baixa Intensidade isolada e associada ao óleo de Calendula officinalis no reparo de úlceras em pé diabético. Método: Estudo de caso clínico, experimental, controlado, randomizado, prospectivo, intervencional, de caráter quantitativo. A amostra foi composta de 32 pacientes diabéticos, de ambos os gêneros. Os participantes foram distribuídos aleatoriamente em quatro grupos. Ultrassom Doppler, avaliação do Índice Tornozelo-Braquial, Inventário breve de dor e escala de dor analógica foram realizados no início e após 30 dias. Resultados: Houve redução da dor nos grupos Terapia a Laser de Baixa Intensidade e Terapia a Laser de Baixa intensidade associada aos Ácidos Graxos Essenciais, com p<0,01. Quanto ao Índice Tornozelo-Braquial e Ultrassom Doppler, todos os grupos mantiveram-se estáveis. Na análise da redução de área da lesão, o grupo Terapia a Laser de Baixa Intensidade associada aos Ácidos Graxos Essenciais apresentou uma significância p=0,0032, e o grupo Terapia a Laser de Baixa Intensidade, p=0,0428. Conclusão: A Terapia a Laser de Baixa Intensidade, realizada tanto isoladamente quanto associada ao óleo de Calendula officinalis, foi eficaz no alívio da dor e na aceleração do processo de reparo tecidual de pé diabético.

\section{DESCRITORES}

Calendula Officinalis; Diabetes Mellitus; Pé Diabético; Terapia a Laser.

\section{RESUMEN}

Objetivo: Evaluar los efectos de la Terapia con Láser de Baja Intensidad aislada y asociada con el aceite de Calendula officinalis en la reparación de úlceras en pie diabético. Método: Estudio de caso clínico, experimental, controlado, randomizado, prospectivo, intervencionista, de carácter cuantitativo. La muestra estuvo compuesta de 32 pacientes diabéticos, de ambos géneros. Los participantes fueron distribuidos aleatoriamente en cuatro grupos. Ecografía Doppler, evaluación del Índice Tobillo-Brazo, Inventario breve de dolor y escala visual analógica fueron realizados al inicio y después de 30 días. Resultados: Hubo reducción del dolor en los grupos Terapia con Láser de Baja Intensidad y Terapia con Láser de Baja intensidad asociada con los Ácidos Grasos Esenciales, con p<;0,01. En cuanto al Índice Tobillo-Brazo y la Ecografía Doppler, todos los grupos se mantuvieron estables. En el análisis de la reducción del área de la lesión, el grupo Terapia con Láser de Baja Intensidad asociada con los Ácidos Grasos Esenciales presentó una significación p=0,0032, y el grupo Terapia con Láser de Baja Intensidad, $\mathrm{p}=0,0428$. Conclusión: La Terapia con Láser de Baja Intensidad, llevada a cabo tanto aisladamente como asociada con el aceite de Calendula officinalis, fue eficaz en el alivio del dolor y la aceleración del proceso de reparación de tejidos del pie diabético.

\section{DESCRIPTORES}

Calendula Officinalis; Diabetes Mellitus; Pié Diabético; Terapia por Láser. 


\section{REFERENCES}

1. Ochoa O, Torres FM, Shireman PK. Chemokines and diabetic wound healing. Vasc 2007;15(6):350-5.

2. Abreu AM, Oliveira BG. A study of the Unna Boot compared with the elastic bandage in venous ulcers: a randomized clinical trial. Rev Latino Am Enfermagem. 2015; 23(4):571-7.

3. Hogarth, PJ. The biology of mangroves and seagrasses. Oxford: University Press, 2015.

4. Schaper NC, Andros G, Apelqvist J, Bakker K, Lammer J, Lepantalo M, et al. Diagnosis and treatment of peripheral arterial disease in diabetic patients with a foot ulcer: a progress report of the International Working Group on the Diabetic Foot. Diabetes Metab Res Rev. $2012 ; 28(1): 218-4$

5. Moreira FF, Oliveira ELP, Barbosa FS, Silva, JG. Laserterapia de baixa intensidade na expressão de colágeno após lesão muscular cirúrgica. Fisioter Pesq. 2011;18(1):37-42.

6. Brasil. Ministério da Saúde; Agência Nacional de Vigilância Sanitária. Instrução Normativa n.5, de 11 de dezembro de 2008. Determina a publicação da Lista de Medicamentos Fitoterápicos de Registro Simplificado [Internet]. Brasília; 2008 [citado 2015 out. 22]. Disponível em: http://bvsms.saude.gov.br/bvs/saudelegis/anvisa/2005/int0005_11_12_2008.html

7. Pristo I. Cicatrização de feridas: fases e fatores de influência. Act Vet Bras. 2013; 6(4):267-71.

8. Brownrigg JRW, Bruin JL, Rossi L, Karthikesalingam A, Patterson B, Holt PJ, et al. Endovascular aneurysm sealing for infrarenal abdominal aortic aneurysms: 30-day outcomes of 105 patients in a single centre. Eur J Vasc Endovasc Surg. 2015;50(2):157-64.

9. Kawamura T. Índice Tornozelo-Braquial (ITB) determinado por esfigmomanômetros oscilométricos automáticos. Arq Bras Cardiol. 2008;90(5):322-6.

10. Wen XR, Lü XF, Liu CC, Luo Y, Chen DW, Wang C, et al. The ultrasound image characteristics of lower extremities arteries in diabetic foot [abstract]. Sichuan Da Xue Xue Bao Yi Xue Ban. 2012;43(5):739-42.

11. Torres AGMJ, Machado EG, Lopes TS, Gentile PC, Vieira AC, Soares LG, et al. Prevalência de alteração do índice tornozelo-braço em indivíduo portador assintomático de doença arterial obstrutiva periférica. Rev Bra Cardiol. 2015;25(2): 87-93.

12. Santos MDL, Santos VA, Santos WF, Silva JS, Wanderley AMPS, et al. Comparação dos valores do índice tornozelo-braquial entre idosos diabéticos e não diabéticos. Rev Humano Ser. 2015;1(1):18-31.

13. Huang YY, Chen AC, Carroll JD, Hamblin MR. Biphasic dose response in low level light therapy. Dose Response. 2009;7(4):358-83.

14. Honório-França AC, Marins CMF, Boldrini F, França EL. Evaluation of hypoglicemic activity and healing of extract from amongst bark of" Quina do Cerrado"(Strychnos pseudoquina ST. HILL). Acta Cir Bras. 2008;23(6):504-10.

15. Zhang Q, Andrew Chan KL, Zhang G, Gillece T, Senak L, Moore DJ, et al. Raman microspectroscopic and dynamic vapor sorption characterization of hydration in collagen and dermal tissue. Biopolymers. 2011;95(9):607-15. 